
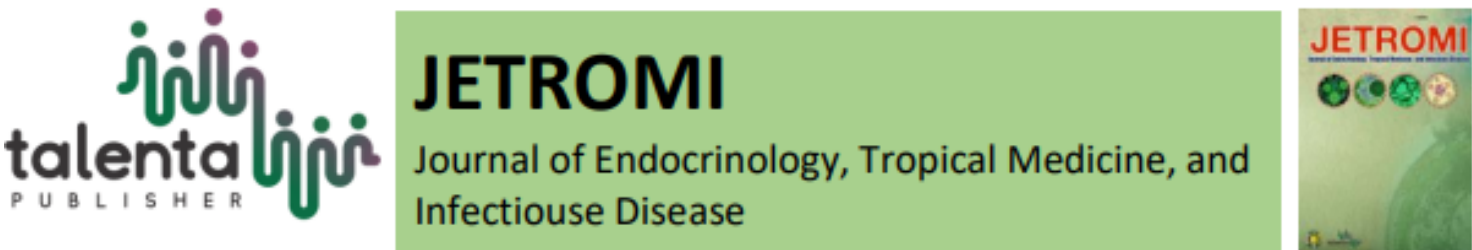

\title{
Fournier Gangrene in Newly Diagnosed Diabetes Mellitus Patient: A Case Report
}

\author{
Annisa Nidya Rahmatika Sitepu*, Santi Syafril \\ Department of Internal Medicine, Faculty of Medicine, University of Sumatera Utara, Medan, North \\ Sumatera, Indonesia
}

\begin{abstract}
Background: Fournier gangrene (FG) is a rare but life-threatening necrotizing fasciitis of the external genitalia, perineal area, or perianal caused by a combination of aerobic and anaerobic bacterial infection. It has a higher incidence in men with risk factors including diabetes, HIV, alcoholism, and other immunocompromised states. Case presentation: A man, aged 62, was admitted to the hospital complaining of ulcers on his testicles. The patient feels that his testicles are getting swollen, painful, and red. Ulcers appear black, accompanied by pus and accompanied by a foul smell. The patient was hematoligic examination, radiologic and blood cultur and diagnosed with Fournier's gangrene on scrotal area and T2DM. The patient is subjected to immediate debridement and is given broad-spectrum antibiotic therapy, administration of insulin, and monitoring of blood sugar. Conclusion: the reported a case of Fournier gangrene being comprehensive management, causing the prognosis to good improvement.
\end{abstract}

Keyword: Fournier gangrene, T2DM

\begin{abstract}
Abstrak. Latar belakang: Fournier Gangrene (FG) merupakan suatu fasciitis nekrotikans langka namun mengancam nyawa pada genitalia eksterna, daerah perineal, atau perianal yang disebabkan oleh gabungan infeksi bakteri aerob dan anaerobik. Penyakit ini memiliki insiden yang lebih tinggi pada laki-laki dengan faktor risiko termasuk diabetes, HIV, alkoholisme, dan keadaan imunokompromise lainnya. Presentasi Kasus: Seorang pria, berusia 62 tahun, dirujuk ke rumah sakit dengan keluhan luka borok pada buah zakarnya. Pasien merasakan buah zakarnya semakin membengkak, nyeri dan memerah. Luka borok tampak menghitam, disertai nanah dan disertai bau busuk. Pasien dilakukan pemeriksaan darah dan radiologi di diagnosis dengan Fournier gangrene scrotal area dan DMT2. Selanjunya pasien dilakukan debridemen segera, dan diberikan terapi antibiotik spektrum luas, pemberian insulin, dan dilakukan pemantauan gula darah. Kesimpulan: dilaporkan seorang kasus Fournier gangrene yang ditangani secara komprehensif, menyebabkan perbaikan prognosa.
\end{abstract}

Kata Kunci: Fournier gangrene; DMT2

Received 14 October 2020 | Revised 23 November 2020 | Accepted 30 November 2020

\footnotetext{
*Corresponding author at: Department of Internal Medicine, Faculty of Medicine, University of Sumatera Utara, Medan, North Sumatera, Indonesia

E-mail address: annisa.nidya94@gmail.com
} 


\section{Introduction}

Fournier gangrene (FG) is a rare but life-threatening necrotizing fasciitis of the external genitalia, perineal area, or perianal caused by a combination of aerobic and anaerobic bacterial infection. It has a higher incidence in men, the ratio of men to women is $10: 1$, with risk factors including diabetes, HIV, alcoholism, and other immunocompromised states [1-3]. Fournier's gangrene is a surgical emergency because its onset is very sudden, progresses rapidly, can become widespread gangrene, and cause septicemia. The rapid progression and severity of gangrene which often fulminates can lead to multiple organ failure and death. Disease hostility is associated with a high mortality rate which ranges from $20 \%$ to as high as $70 \%$ to $80 \%$. In the National Database Investigate, The Epidemiology of Fournier's gangrene revealed the mortality rate of Fournier's gangrene patients acquired 20-40\% with an incidence rate of $88 \%$ [1-4]. Although antibiotics and debridement have been widely accepted as standard treatments, mortality remains high. Besides, the increasing age and prevalence of diabetes in the population demands increased clinical awareness of FG with an emphasis on early diagnosis and management [1-3].

\section{Case Illustration}

A 62 years old man, was referred to the H. Adam Malik central public hospital on November 3rd, 2020 , with chief complaints of an ulcer in his scrotum. This was experienced by the patient for \pm 6 days before being admitted to the hospital. Initially, the patient complained of pain when urinating \pm 2 weeks before admission to the hospital, and then the patient felt the testicles get swollen, painful, and red. Ulcers appear black, accompanied by pus and accompanied by a foul smell (Fig.1). Fever encountered since five days ago, felt intermittent high fever and down with fever medications. Cough and shortness of breath are denied. The history of contact or exposure to Covid-19 patients within 14 days is denied. Decreased appetite was found in this 1 week. A history of pain when urinate was found 2 weeks ago, reddish urine, frothy, or accompanied by sand was not found. The patient was referred from Mitra Sejati Hospital with a diagnosis of Fournier Gangrene. 


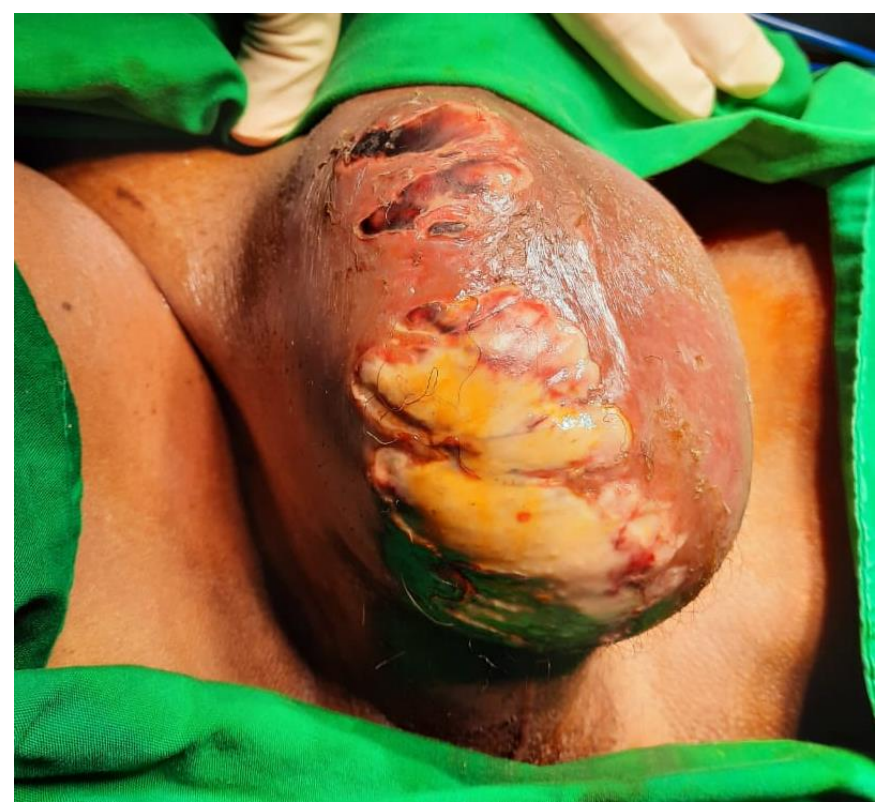

Figure 1 Patient's clinical of scrotum on hospital admission

From the examination, the patient with bodyweight $64 \mathrm{~kg}$ and height $165 \mathrm{~cm}$ with BMI 23.50 $\mathrm{Kg} / \mathrm{m} 2$ were normal weight. The pulse rate was 88 times/min, blood pressure of $120 / 70 \mathrm{mmHg}$, a respiratory rate of 18 breaths $/ \mathrm{min}$, a temperature of $36.7^{\circ} \mathrm{C}$. Physical examination of the genitalia, scrotum: edema $(+)$, erythema $(+)$, pus $(+)$, necrotic $(+)$, tenderness $(+)$. Another physical examination within normal limits. From a complete blood count, patients with $\mathrm{Hb}$ $12.3 \mathrm{~g} / \mathrm{dL}$, leukocytes $14,720 / \mu \mathrm{L}$, platelets of $434,000 / \mu \mathrm{L}$, neutrophils $81.4 \%$, and lymphocytes 9.6\%. From the blood gas analysis, patient with $\mathrm{pH} / \mathrm{pCO} 2 / \mathrm{pO} 2 / \mathrm{HCO} 3 / \mathrm{TCO} 2 / \mathrm{BE} / \mathrm{SO} 2: 7.360 / 14 / 198 / 7 / 7.4 /-16.6 / 100$ with fully compensated metabolic acidosis. The patient's ad-random blood glucose was $160 \mathrm{mg} / \mathrm{dL}$, procalcitonin of 0.36 $\mathrm{ng} / \mathrm{mL}$, hypoalbuminemia of $2.6 \mathrm{~g} / \mathrm{dL}$. The electrolyte, sodium $138 \mathrm{mEq} / \mathrm{L}$, potassium $4.4 \mathrm{mEq} / \mathrm{L}$, and chloride of $102 \mathrm{mEq} / \mathrm{L}$. From the electrocardiogram, it was found sinus rhythm. From the chest radiograph, it was found within normal limits. The patient was then diagnosed with Fournier Gangrene o/t scrotal area and hypoalbuminemia. The patient then insertion of a urinary catheter, was given an injection of ceftriaxone $2 \mathrm{gr} / 24$ hours, drips of metronidazole $500 \mathrm{mg} / 8$ hours, albumin $3 \times 1 \mathrm{sacc}$, and paracetamol tablet $2 \times 1000 \mathrm{mg}$ for the pain. The patient then underwent immediate extensive surgical debridement with excision of all necrotic tissues and adequate open drainage (Fig.2). 


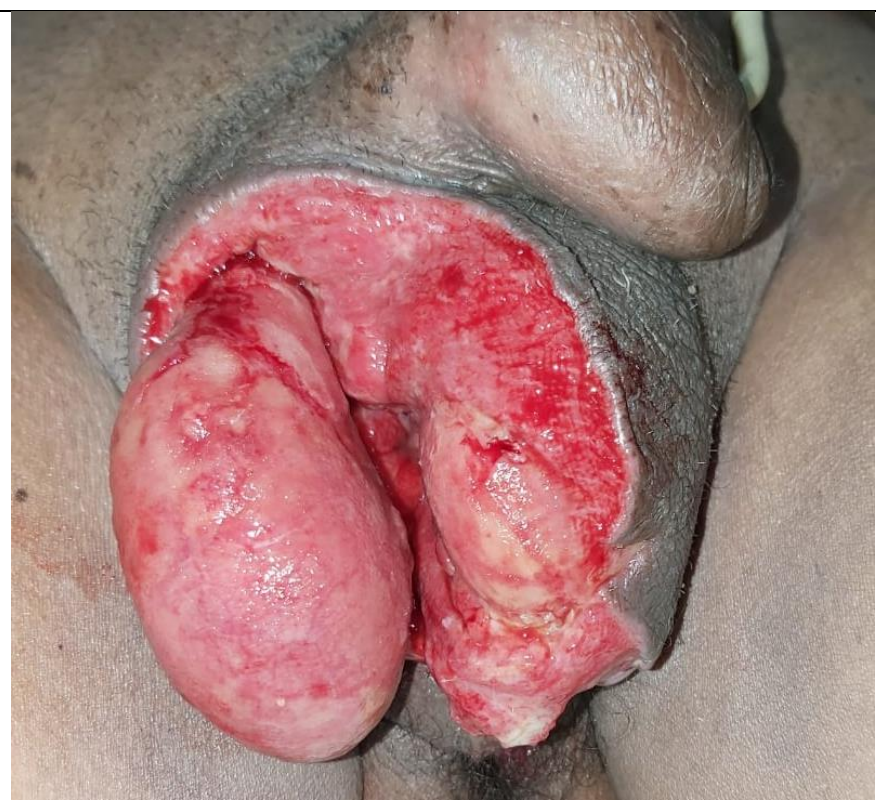

Figure 2 Patient's clinical postoperative scrotum and completely exposed testes.

On the next day, patient's fasting blood glucose of $127 \mathrm{mg} / \mathrm{dL}$, a 2-hour postprandial blood glucose of $151 \mathrm{mg} / \mathrm{dL}, \mathrm{HbA} 1 \mathrm{c}$ of $6.6 \%$, total cholesterol of $131 \mathrm{mg} / \mathrm{dL}$, triglycerides of $45 \mathrm{mg} / \mathrm{dL}, \mathrm{HDL}$ of $51 \mathrm{mg} / \mathrm{dL}$ and LDL of $64 \mathrm{mg} / \mathrm{dL}$. From a complete blood count, patients with $\mathrm{Hb} 11.4 \mathrm{~g} / \mathrm{dL}$, leukocytes $14,480 / \mu \mathrm{L}$, platelets of $450,000 / \mu \mathrm{L}$, neutrophils $77.3 \%$, and lymphocytes $10.7 \%$, procalcitonin of $0,39 \mathrm{ng} / \mathrm{mL}$. The patient was then diagnosed with a Fournier gangrene o/t scrotal area (post debridement) with T2DM and hypoalbuminemia. The patient was then given a 1900 kcal diet DM, was changed the antibiotic to an injection of meropenem 1gr/8 hours, drips of metronidazole $500 \mathrm{mg} / 8$ hours, VIP albumin $3 \times 1 \mathrm{sacc}$, and paracetamol tablet $2 \times 1000 \mathrm{mg}$ for the pain, and was planned to monitor the fasting and 2-hour postprandial blood glucose. On the 7th of November 2020, the patient was checked for another complete blood count to evaluate the antibiotic. From a complete blood count, patients with $\mathrm{Hb} 11.4 \mathrm{~g} / \mathrm{dL}$, leukocytes 7,810/ $\mu \mathrm{L}$, platelets of $449,000 / \mu \mathrm{L}$, neutrophils $58.2 \%$, and lymphocytes $27 \%$, procalcitonin of $0,08 \mathrm{ng} / \mathrm{mL}$, fibrinogen of $265 \mathrm{mg} / \mathrm{dL}$, and d-dimer $400 \mathrm{ng} / \mathrm{mL}$. From the pus culture, there was no bacterial growth found. From the urinalysis, it was found within normal limits. The patient's fasting blood glucose of $125 \mathrm{mg} / \mathrm{dL}$, 2-hour postprandial blood glucose of $209 \mathrm{mg} / \mathrm{dL}$. The patient was given additional insulin injection therapy (Aspart insulin 6-6-6 U/SC). The patient was then screened for fasting blood glucose and 2-hour postprandial per 2 days for monitoring blood glucose levels to maintain a fasting blood glucose level of 90 to $130 \mathrm{mg} / \mathrm{dL}$ and a 2-hour postprandial blood glucose level of 140 to $180 \mathrm{mg} / \mathrm{L}$. On the 10th of November, 2020, the patient underwent the second surgical debridement and re-construction (Fig.3). As the patient's blood sugar began to preserve, insulin administration via subcutaneous insulin injections was continued. The patient was then discharged from the hospital on the 12th of November 2020. 


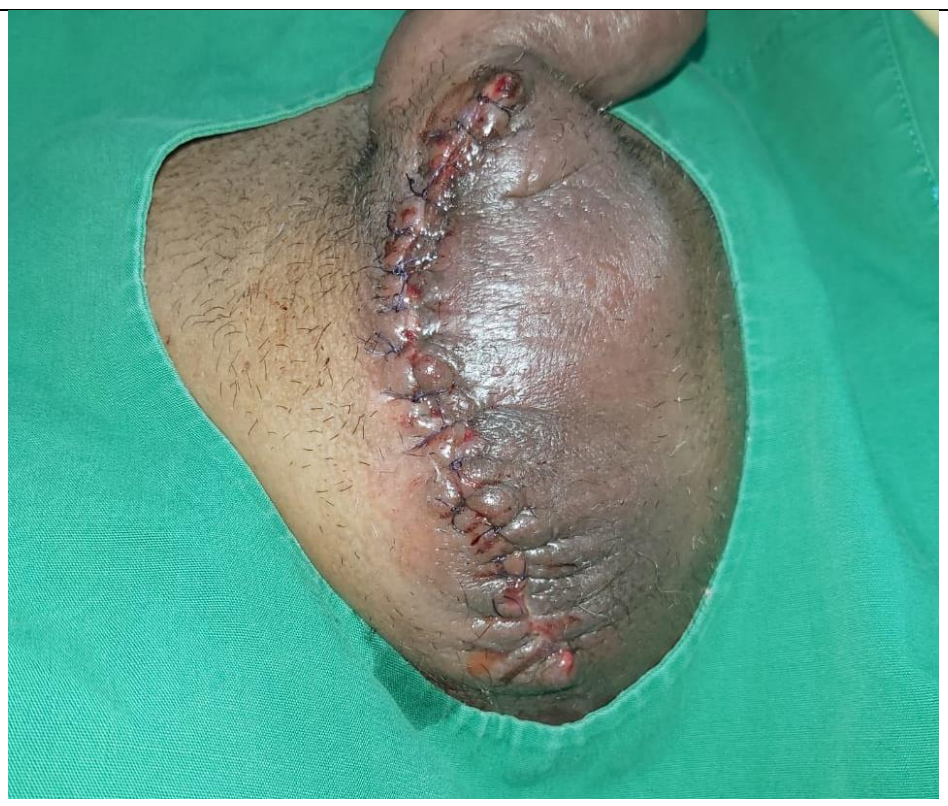

Figure 3 Patient's scrotum after re-construction

\section{Discussion}

Fournier's gangrene is a type I necrotizing fasciitis of the perineal, perianal, or genital areas. Over the years, FG has been known by several names, such as 'streptococcus gangrene', 'synergistic necrotizing cell cellulitis', and 'periurethral phlegmon', all of which describe infective, destructive, and fatal soft tissue disease $[4,6]$. FG was first discovered in 1883 , by a genital disease expert from France, Jean Alfred Fournier found that 5 previously healthy young men suffered from gangrene rapidly progressing to the penis and scrotum for no apparent reason. Infection of Fournier's gangrene had a characteristic, which might induce thrombosis of the subcutaneous vessels resulting in skin necrosis in the vicinity [1-4]. Necrotizing fasciitis often results from infection of the anorectal (30-50\%), urogenitalia (20-40\%), or genital skin (20\%) [5].

This disease approach often results from polymicrobial aerobic and anaerobic synergistic infection of the fascia. Similar to necrotizing fasciitis, gram-positive bacteria such as Group A Streptococci and gram-negative bacteria such as E. Coli and Pseudomonas aeruginosa are organisms most commonly grown in wound cultures of Fournier gangrene patients. These bacteria can get introduced through several different sources, including urinary, bowel, or dermal. Urinary tract infections and other infectious processes of the perineum, such as perianal abscesses, also provide a nidus for infection. Surgical manipulation of the genital and perineal area similarly can provide the initial insult required in the development of Fournier gangrene. Additionally, trauma to the area, whether intentional or unintentional, leading to skin breakdown can provide bacteria with a path to the fascia and subsequent development of the disease [6].

FG is strongly associated with diabetes, chronic alcoholism, human immunodeficiency virus (HIV), lymphoproliferative disease, chronic steroid abuse, and cytotoxic drugs [5,7,8]. The most common comorbid systemic disorders are diabetes mellitus and alcohol abuse. Diabetes mellitus 
is reported to emerge in 20\%-70\% of patients with FG and chronic alcoholism in 25\%-50\% of patients. The emergence of HIV into epidemic proportions has opened up broad populations at risk for developing FG. The principle underlying all of these conditions is decreased host immunity, thus creating a favorable environment for infection to occur. Malnutrition and lower socioeconomic status have also been shown to be linked to the development of FG. Both of these factors are potentially associated with inadequate perineal hygiene and lower immunity associated with the outcome of FG [5,7-10]. DM has been associated with the reduced response of T cells, neutrophil function, and disorders of humoral immunity. Consequently, DM increases the susceptibility to infections, both the most common ones as well as those that almost always affect only people with DM [4,11]. Diabetes mellitus can affect the immune system. Hyperglycemia in the bloodstream damages the walls of blood vessels, especially capillaries. If the blood vessels are damaged, oxygen flow is blocked, making wound healing became difficult [2]. Continued hyperglycemia has a detrimental effect on the immunity of patients through its adverse effects on cellular adherence, chemotaxis, and phagocyte activity. Infectious diseases are more common in individuals with DM. The main pathogenic mechanisms are: a hyperglycemic environment increases the virulence of some pathogens; lower interleukin production in response to infection; decreased chemotaxis and phagocytic activity, immobilization of polymorphonuclear leukocytes; glycosuria, gastrointestinal and urinary disorders [4]. The presence of a localized infection adjacent to the portal of entry allows the entry of commensal bacteria, such as Staphylococcus spp, and Escherichia coli into the perineum. The infectious organism triggers an inflammatory response that results in micro thrombosis of the small subcutaneous vessels. Thrombosis results in diminished blood flow to this area, triggering tissue ischemia that causes the development of gangrene in the overlying skin. The reduced oxygen tension of the tissues promotes further anaerobic bacteria proliferation and fascial necrosis [4].

Bacteremia is considered a starting link in the mechanism of the expansion of necrosis of the fascia, initiates the cytokine cascade leading to the damage of the endothelium. In turn, it activates utilizing thromboplastin, a coagulation cascade with inhibition of fibrinolysis and the formation of disseminated micro thrombosis of vessels feeding the fascia. Besides, damage to the endothelium leads to extravasation of the liquid part of the blood, swelling of tissues, leukocyte infiltration, all leading to the ischemic necrosis of the fascia [1].

Although initially described as a sudden onset, studies have shown that this condition often has a slower onset. Pruritus symptoms, pain, and discomfort generally tend to worsen for 3-5 days before admission. The typical sign of Fournier gangrene includes prodromal symptoms of fever and lethargy, which may be present for two to seven days, intense genital pain and tenderness that is usually associated with edema of the overlying skin, increasing genital pain and tenderness with progressive erythema of the overlying skin, the dusky appearance of the overlying skin; subcutaneous crepitation, obvious gangrene of a portion of the genitalia; purulent drainage from the wounds $[1,9]$. 
The examination may show purulent discharge, crepitus, and patches of necrotic tissue with surrounding edema. The skin manifestations tend to appear later in the disease process as these patches develop into fluoride gangrene. A thorough history, revealing diabetes, chronic alcohol abuse, steroid abuse, HIV, malignancy, lymphoproliferative disease as well as recent catheterization, instrumentation, and perineal trauma, should all raise the index of suspicion for soft tissue necrotizing infection. Although the diagnosis of FG can only be confirmed after surgical exploration, laboratory studies and radiological evaluation are useful diagnostic tools in risk assessment $[1,9]$.

Given the high mortality and rapid progression to moribund status, multiple risk calculators have been developed to facilitate the early evaluation of disease severity [9]. Laor et al developed a scoring system (Fournier's gangrene severity index), to measure the severity of infection, using general vital signs and laboratory data. A score of $>10.5$ is associated with a $96 \%$ probability of death and a score of $\leq 10.5$ a $96 \%$ probability of survival.

Proactive management of diabetic patients and immunosuppression with perineal infection is very important to prevent worsening of the condition as the presence of comorbidities is associated with high mortality. FG guarantees an aggressive multimodal approach, which includes hemodynamic stabilization, broad-spectrum antibiotics, and surgical debridement. $[1,9,10]$

However, it must be underlined that early surgical debridement is a major component of management and if it is delayed it will worsen the prognosis. All necrotic tissue should be excised until well diffusible tissue is achieved. A parenteral broad-spectrum antibiotic regimen is required in the management of FG. The main treatment with antibiotics, especially for the gram-positive cocci. Anaerobic and MRSA germs can cause the expansion of soft tissue infection along the muscle fascia (fasciitis necroticans). There are currently no recommendations for optimal antibiotic therapy in FG and patient management is dependent on local hospital guidelines $[1,9,10]$.

\section{Conclusion}

We have reported a case of Fournier gangrene with new T2DM. This case showed that the comprehensive infection and glycaemic control accomplished good treatment effects on a fournier gangrene patient with diabetes.

\section{REFERENCES}

[1] Chernyadyev SA, Ufimtseva MA, Vishnevskaya IF, Bochkarev YM, Ushakov AA, Beresneva TA, et al, "Fournier's Gangrene: Literature Review and Clinical Cases," Urologia internationalis. [Online]. Available: https://pubmed.ncbi.nlm.nih.gov/29949811/ 
[2] Z. Zamzami, I. Jaya, M. A. Yashar, and M. Zalena, "Characteristic And Management Fournier'S Gangrene In Arifin Achmad Regional General Hospital Of Riau Province," Indonesian Journal of Urology, vol. 27, no. 2, pp. 111-6, 2020.

[3] D. Koukouras, P. Kallidonis, C. Panagopoulos, A. Al-Aown, A. Athanasopoulos, C. Rigopoulos, E. Fokaefs, J.-U. Stolzenburg, P. Perimenis, and E. Liatsikos, “Fournier's Gangrene, a Urologic and Surgical Emergency: Presentation of a Multi-Institutional Experience with 45 Cases," Urologia Internationalis, vol. 86, no. 2, pp. 167-72, 2011.

[4] A. Singh, K. Ahmed, A. Aydin, M. S. Khan, and P. Dasgupta, "Fournier's gangrene. A clinical review," Arch. Ital. Urol. Androl., vol. 88, no. 3, pp. 157-64, 2016.

[5] B. Kuzaka, M. M. Wróblewska, T. Borkowski, D. Kawecki, P. Kuzaka, G. Młynarczyk, and P. Radziszewski, "Fournier's Gangrene: Clinical Presentation of 13 Cases," Medical Science Monitor, vol. 24, pp. 548-55, 2018.

[6] J. Rad, J. Foreman, Fournier Gangrene. StatPearls Publishing LLC., 2020.

[7] I. Insua-Pereira, P. Costa Ferreira, S. Teixeira, D. Barreiro, Á. Silva, "Fournier's gangrene: a review of reconstructive options," Central European Journal of Urology, vol. 73, pp. 7479, Dec. 2019.

[8] T.-Y. Lin et al., "Incorporating Simplified Fournier's Gangrene Severity Index with early surgical intervention can maximize survival in high-risk Fournier's gangrene patients," Int. J. Urol., vol. 26, no. 7, pp. 737-43, 2019.

[9] C. E. L. Tenório, S. V. C. Lima, A. V. de Albuquerque, M. P. Cavalcanti, and F. Teles, "Risk factors for mortality in fournier's gangrene in a general hospital: use of simplified founier gangrene severe index score (SFGSI)," Int. Braz J Urol, vol. 44, no. 1, pp. 95-101, 2018.

[10] J. Auerbach, K. Bornstein, M. Ramzy, J. Cabrera, T. Montrief, and B. Long, "Fournier gangrene in the emergency department: Diagnostic dilemmas, treatments and current perspectives," Open Access Emerg. Med., vol. 12, pp. 353-64, 2020.

[11] J. Casqueiro, J. Casqueiro, and C. Alves, "Infections in patients with diabetes mellitus: A review of pathogenesis," Indian J. Endocrinol. Metab., vol. 16 Suppl 1, no. 7, pp. S27-36, 2012 . 